\title{
EFEKTIFITAS ECENG GONDOK (Eichornia crassipess) TERHADAP REDUKSI TOTAL AMMONIA NITROGEN (TAN) DAN PERTUMBUHAN BENIH IKAN LELE DUMBO (Clarias gariepinus)
}

\author{
Ega Puspita Famila Boden Junaedi Putri ${ }^{1{ }^{*}}$, Salnida Yuniarti Lumbessy ${ }^{1)}$, dan Nanda Diniarti ${ }^{1)}$ \\ ${ }^{1}$ Program Studi Budidaya Perairan, Fakultas Pertanian, Universitas Mataram \\ Jl. Pendidikan No. 37 Mataram, NTB \\ Email : egabjp22478@gmail.com
}

\begin{abstract}
Catfish (Clarias gariepinus.) is one of the leading commodities that are widely cultivated in Indonesia. The current development of the aquaculture industry, which leads to intensive cultivation systems with an increase in stocking and high amount of feed, causes an increase in organic waste that can reduce water quality. Phytoremediation is one way to stabilize pollutants, both organic and inorganic compounds, through aquatic plants. Water hyacinth (Eichornia crassipess) is one aquatic plant that can reduce total nitrogen up to $73.05 \%$. This study aims to analyze the effect of water hyacinth (E. crassipess) as a phytoremediator on TAN reduction, survival rates, and growth of catfish (C. gariepinus) seeds. This study used a Completely Randomized Design (CRD) method with four treatments and four replications, namely P1/control (without water hyacinth), P2 (without replacement of water hyacinth), P3 (alternation of water hyacinth every 21 days), and P4 (alternation of water hyacinth) every 14 days). The results showed that the P4 treatment (alternation of water hyacinth every 14 days) gave the lowest TAN content $0.01 \mathrm{mg} / \mathrm{L}$ and provided the highest survival rate of $89.88 \%$, as well as the absolute weight and length growth of the most catfish seeds height, i.e., $9.80 \mathrm{~g}$, and $5.50 \mathrm{~cm}$, respectively.
\end{abstract}

Keywords: Phytoremediator, Catfish, Water Hyacinth, Total Ammonia Nitrogen.

\section{PENDAHULUAN}

Ikan Lele (Clarias gariepinus.) merupakan salah satu komoditas unggulan yang banyak dibudidayakan di Indonesia, karena memiliki nilai ekonomis penting. Peningkatan permintaan ikan lele dari tahun ke tahun, menyebabkan terjadinya peningkatan produksi ikan lele. Berdasarkan data Ditjen Perikanan Budidaya Kementerian Kelautan dan Perikanan, produksi lele 2017 mencapai 1,8 juta ton atau melesat 131,7 persen dari pencapaian tahun sebelumnya dan diperkiraan permintaan terus meningkat. Potensi tersebut mendorong minat masyarakat untuk membudidayakan ikan lele.

Pengembangan industri akuakultur saat ini mengarah pada sistem budidaya intensif. Sistem budidaya intensif dapat dilakukan dengan peningkatan pada tebar yang tinggi serta diikuti dengan peningkatan jumlah pakan. Kondisi ini menyebabkan meningkatnya limbah buangan organik yang disebabkan oleh sisa pakan yang tidak termakan, sisa metabolisme yang apabila terakumulasi dapat menurunkan kualitas perairan (Pratiwi, 2015). Limbah buangan organik pada proses budidaya dapat terakumulasi dan menyebabkan penurunan kualitas air. Sebenarnya, air masih dapat melakukan self purification dengan sendirinya, jika beban limbah organik tidak terlalu besar, tetapi jika bahan organik pada sistem budidaya intensif terlalu besar jumlahnya, maka terjadi pencemaran bahan organik pada air yang dapat menyebabkan kematian organisme akuatik. Salah satu pencegahan yang dapat dilakukan untuk meminimalisir bahan organik berbahaya dalam wadah budidaya adalah dengan sistem fitoremediasi (Wulandari, 2015).

Fitoremediasi merupakan penggunaan tumbuhan untuk menghilangkan, memindahkan, menyetabilkan, dan 
KAUDERNI : Journal of Fisheries, Marine and Aquatic Science

https://jurnal.stplpalu.ac.id/index.php/kauderni/index

Volume 2, Nomor 2, (2020)

ISSN 2541-0571

https://doi.org/10.47384/kauderni.v2i2.45

menghancurkan bahan pencemar baik senyawa organik maupun anorganik (Purwaningsih, 2009). Keunggulan metode ini adalah karena prosesnya yang berjalan secara alami dan tidak memerlukan teknologi tinggi.

Salah satu jenis tanaman air yang dapat digunakan pada proses fitoremediasi adalah eceng gondok (Eichornia crassipes). Eceng gondok (E. crassipes) merupakan salah satu tumbuhan air yang banyak dijumpai di perairan tropis seperti rawa, waduk dan danau. Menurut Rahmaningsih (2006) pemanfaatan tanaman eceng gondok (E.crassipes) dalam perairan dapat menurunkan total nitrogen hingga $73,05 \%$, kadar amonia hingga 72,7 \%, kadar nitrat hingga $71,43 \%$. Kemampuan eceng gondok dalam proses penyerapan berbagai unsur hara dan senyawa kimia lainnya dari dalam air dipengaruhi oleh beberapa faktor, diantaranya sistem perakaran eceng gondok yang berakar serabut dan tidak bercabang, lubang stomata eceng gondok yang berukuran dua kali lebih besar dari kebanyakan tumbuhan lain dan jarak antar stomata delapan kali besarnya lubang, serta adanya vakuola dalam struktur sel. Hal inilah yang menyebabkan pertukaran atau penyerapan bahan antar sebuah sel dengan sekelilingnya menjadi lebih efisien.

Hasil penelitian Pratiwi (2015) tentang pemanfaatan fitoremediator eceng gondok (E. crassipes) pada produksi ikan nila (Oreochromis niloticus), menunjukkan bahwa perlakuan eceng gondok $135 \mathrm{~g}$ memberikan hasil paling baik dibandingkan perlakuan tanpa eceng gondok. Abdul (2014) melakukan penelitian tentang peranan eceng gondok sebagai fitoremediator pada media budidaya ikan gurami lac ukuran $3 \mathrm{~cm}$ dalam wadah terkontrol, menunjukan bahwa penggunaan eceng gondok dengan bobot 135 $\mathrm{g}$ sebagai fitoremediator memberikan pengaruh nyata terhadap pemeliharaan benih ikan gurami. Berdasarkan uraian dan acuan diatas maka penelitian ini dilakukan untuk melihat pengaruh pemanfaatan eceng gondok sebagai fitoremediator pada budidaya benih ikan lele.

\section{METODE PENELITIAN}

Penelitian ini dilaksanakan selama 42 hari di Pusat Pengembangan Agribisnis SMK PP Mataram, Lombok Barat, dan Laboratorium Balai Kesehatan Perikanan dan Lingkungan Budidaya, Mataram untuk analisis kualitas air. Metode yang digunakan dalam penelitian ini adalah Rancangan Acak Lengkap (RAL) dengan 4 perlakuan dan 4 kali ulangan. Perlakuan yang digunakan adalah perbedaan frekuensi pergantian tanaman eceng gondok yang terdiri atas :

Perlakuan 1: Tanpa eceng gondok (Kontrol). Perlakuan 2: Tanpa pergantian eceng gondok. Perlakuan 3: Pergantian eceng gondok pada hari ke 21.

Perlakuan 4: Pergantian eceng gondok pada hari ke 14.

\section{Prosedur Penelitian}

Persiapan kolam ukuran 50x50 cm dilakukan dengan beberapa proses yaitu pengeringan kolam selama 24 jam, dan dilakukan pemupukan selama 5 hari. Hewan uji yang digunakan dalam penelitian ini adalah benih ikan lele dengan ukuran $5 \mathrm{~cm}$ dengan berat $\pm 1 \mathrm{~g}$. dengan padat tebar 200 ekor $/ \mathrm{m}^{2}$ untuk setiap perlakuan. Ikan dipelihara selama 42 hari, dan diberi makan sebanyak 3 kali sehari Sebanyak 5\% yaitu pagi, siang dan sore hari. Disiapkan juga tanaman air eceng gondok dengan berat $1 \mathrm{~kg}$ dan dibersihkan dengan air mengalir selanjutnya diaklimatisasi sebelum penelitian. Aklimatisasi tanaman dilakukan dengan mengadaptasikan tanaman pada media air dalam kolam selama 7 hari. Selama pemeliharaan tidak dilakukan pergantian air, tetapi anya dilakukan penambahan air untuk mempertahankan volume air dalam media pemeliharaan, untuk mengetahui kemampuan tumbuhan menyerap limbah organik. Eceng gondok di ganti sesuai dengan perlakuan yang dilakukan yaitu diganti setiap 21 hari (P3), dan diganti setiap 14 hari (P4).

\section{Parameter Pengamatan}

Parameter yang diamati adalah kadar TAN air pemeliharaan yang diukur dengan alat spektrofotometri, tingkat kelangsungan hidup, panjang mutlak, berat mutlak. Data 
KAUDERNI : Journal of Fisheries, Marine and Aquatic Science

https://jurnal.stplpalu.ac.id/index.php/kauderni/index

Volume 2, Nomor 2, (2020)

ISSN 2541-0571

https://doi.org/10.47384/kauderni.v2i2.45

yang diperoleh diuji menggunakan Analysis of Variances (ANOVA) pada taraf kepercayaan $95 \%$ melalui software SPSS. Apabila hasil analisis statistik menunjukkan pengaruh yang berbeda nyata, maka dilakukan uji lanjut untuk mengetahui perlakuan terbaik.

\section{HASIL DAN PEMBAHASAN}

Total Ammonia Nitrogen (TAN)

Kadar Total Ammonia Nitrogen

(TAN) pada penelitian ini berkisar antara
$0,007-0,023 \mathrm{mg} / \mathrm{L}$ kisaran ini masih sesuai untuk budidaya ikan lele (Gambar 1), Hasil penelitian Hastuti dan Subandiyono (2015) menunjukkan bahwa ikan lele mampu mentoleransi amonia sampai $5,70 \mathrm{mg} / \mathrm{L}$. Berdasarkan nilai rata-ratanya maka perlakuan frekuensi pergantian eceng gondok setiap 14 hari (P4) memberikan kadar TAN yang paling rendah yaitu $0,01 \mathrm{mg} / \mathrm{L}$. sementara perlakuan tanpa eceng gondok (P1/kontrol) memberikan kadar TAN yang paling tinggi yaitu $0,02 \mathrm{mg} / \mathrm{L}$.

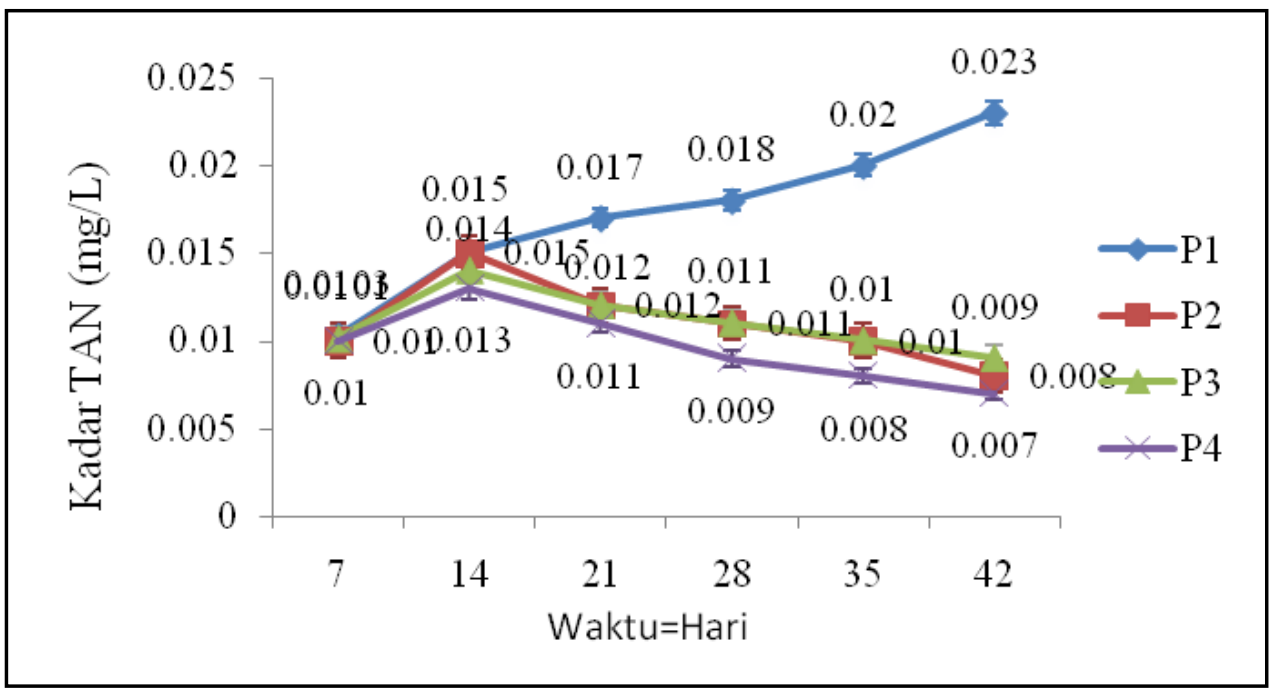

Gambar 1. Pengaruh Frekuensi Pergantian Eceng Gondok Terhadap Kadar TAN

Penurunan kadar TAN pada perlakuan frekuensi pergantian tanaman eceng gondok setiap 14 hari (P4) diduga karena tanaman eceng gondok dapat memanfaatkan ammonia nitrogen dalam bentuk ammonium secara langsung yang berasal dari sisa metabolisme ikan dan sisa pakan. Penurunan kadar ammonia tersebut diduga karena eceng gondok memiliki akar yang bercabangcabang halus, dimana permukaan akarnya digunakan olek bakteri nitrifikasi sebagai tempat tinggal hidupnya dan melakukan pertumbuhan (Tosepu, 2012). Pada perlakuan frekuensi tanpa menggunakan eceng gondok (P1) didapatkan kadar ammonia yang terus meningkat setiap minggunya dikarenakan terakumulasinya sisa-sisa metabolime ikan sehingga kadar ammonia terus meningkat, hal ini dapat menyebabkan kematian pada ikan lele. Menurut Hermawan et al. (2012), menyatakan bahwa ikan lele masih dapat hidup pada kisaran amoniak $0,5-3,8 \mathrm{mg} / \mathrm{L}$

Di dalam air, ammonia terdapat dalam dua bentuk, yakni; $\mathrm{NH}_{4}^{+}$(ammonia terionisasi) dan $\mathrm{NH}_{3}$ (tak terionisasi). Menurut EPA (2013), ammonia $\left(\mathrm{NH}_{3}\right)$ dan senyawa ammonia $\left(\mathrm{NH}_{4}^{+}\right)$lainnya dihasilkan oleh dekomposisi bahan organik, hewan mati, dan ekskresi ikan. Nitrogen tidak dapat dimanfaatkan secara langsung oleh tumbuhan akuatik dan harus mengalami fiksasi terlebih dahulu menjadi ammonia,amonium,nitrat (Putri, 2014). Nitrogen di dalam air terdiri dari bermacam-macam senyawa, namun yang bersifat toksik terhadap ikan dan organisme akuatik lainnya adalah ammonia dan nitrit. 
KAUDERNI : Journal of Fisheries, Marine and Aquatic Science

https://jurnal.stplpalu.ac.id/index.php/kauderni/index

Volume 2, Nomor 2, (2020)

ISSN 2541-0571

https://doi.org/10.47384/kauderni.v2i2.45

\section{Tingkat Kelangsungan Hidup (Survival rate)}

Tingkat kelangsungan hidup dipengaruhi oleh faktor biotik dan abiotik. Rika (2008) menyatakan bahwa parasite, kompetitor, umur, kemampuan adaptasi, penanganan manusia dan kepadatan populasi merupakan faktor biotik. Sifat kimia dan fisika dari suatu lingkungan air merupakan faktor abiotik.

Hasil penelitian ini menunjukan bahwa rata-rata tingkat kelangsungan hidup ikan lele yang dipelihara selama 42 hari dengan berbagai frekuensi pergantian eceng gondok berkisar antara 71,63-89,88\%. Secara umum Trend tingkat kelangsungan hidup ikan lele meningkat sejalan dengan peningkatan frekuensi pergantian eceng gondok. Dimana perlakuan frekuensi pergantian eceng gondok setiap 14 hari sekali (P4) memberikan ratarata tingkat kelangsungan hidup tertinggi sebesar $89,88 \%$, dan yang terendah pada perlakuan frekuensi tanpa eceng gondok (P1) sebesar 71,63\% (Gambar 2)
Hasil Analysis Of Variane (ANOVA) menunjukan bahwa perlakuan frekuensi pergantian tanaman eceng gondok memberikan pengaruh yang sangat nyata $(\mathrm{P}<$ $0,05)$ dengan tingkat kepercayaan 95\% terhadap tingkat kelangsungan hidup benih ikan lele. Sementara hasil uji lanjut Duncan menunjukan bahwa perlakuan frekuensi pergantian eceng gondok setiap 14 hari sekali (P4), memberikan tingkat kelangsungan hidup benih ikan lele yang paling baik dan berbeda nyata dengan semua perlakuan lainnya. Tingkat kelangsungan hidup pada hasil penelitian ini sedikit lebih rendah daripada penelitian pada ikan gurami yang dilakukan oleh Abdul (2014), dimana tingkat kelangsungan hidup pada ikan gurami yang dipelihara selama 30 hari dengan perlakuan eceng gondok sebagai fitoremediator berkisar antara 95,33-97,83\%, berbeda jauh dengan perlakuan kontrol sebesar $24,5 \%$. Hal ini menunjukan bahwa pemberian eceng gondok sangat berpengaruh besar dalam meningkatkan kehidupan ikan lele.

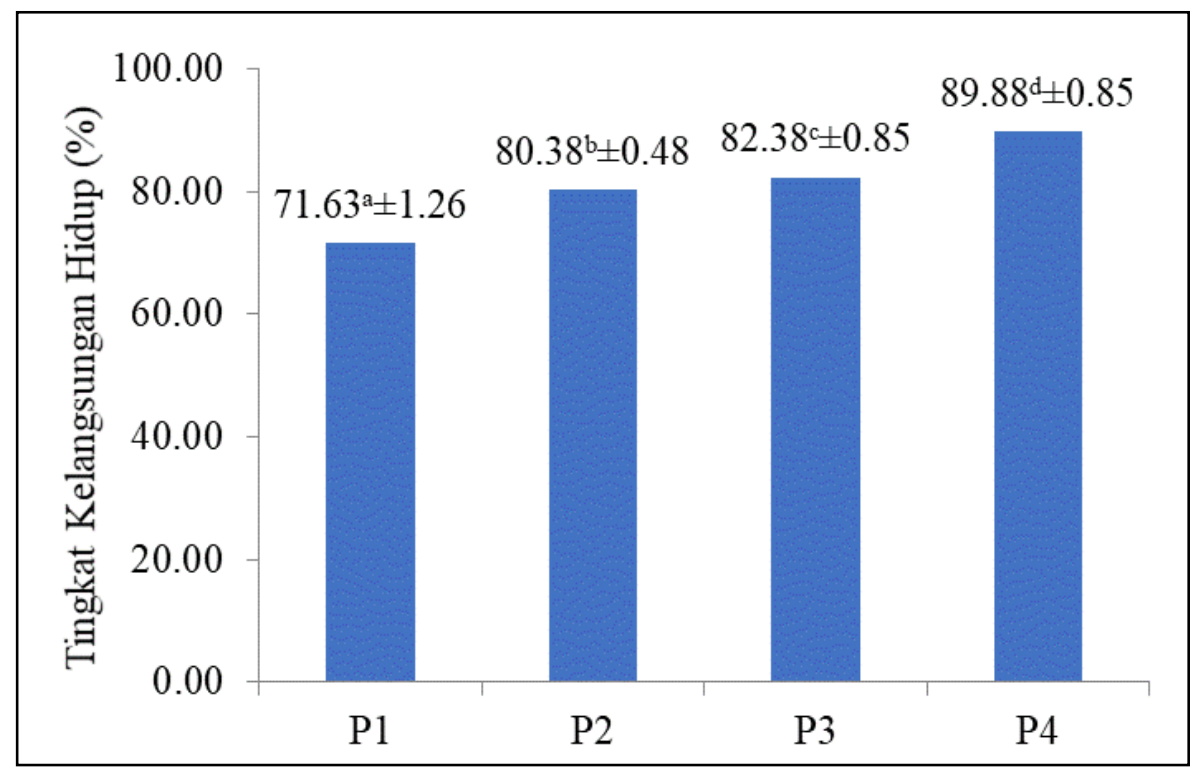

Gambar 2. Pengaruh Frekuensi Pergantian Eceng Gondok Terhadap Tingkat Kelangsungan Hidup Benih Ikan Lele (C. gariepinus)

Panjang Mutlak Benih Ikan Lele

Panjang mutlak adalah salah satu bagian dari sebuah pertumbuhan adalah proses biologis yang kompleks yang dipengaruhi oleh berbagai faktor (Effendie, 2002).

Hasil penelitian menunjukan bahwa Panjang mutlak ikan lele yang dipelihara selama 42 hari dengan berbagai frekuensi 
pergantian eceng gondok berkisar antara 2,66-5,50 cm. Secara umum Trend panjang mutlak benih ikan lele meningkat sejalan dengan peningkatan frekuensi pergantian eceng gondok. Nilai rata-rata panjang mutlak tertinggi terdapat pada perlakuan frekuensi pergantian eceng gondok setiap 14 hari sekali (P4) sebesar $5,50 \mathrm{~cm}$ dan terendah pada perlakuan frekuensi tanpa eceng gondok (P1) sebesar 2,66 cm (Gambar 3).

Hasil Analysis Of Variane (ANOVA) menunjukan hasil yang sangat nyata $(\mathrm{P}<$ $0,05)$ dengan tingkat kepercayaan $95 \%$ antara perlakuan P1 sebesar 2,66 $\mathrm{cm}$ dengan perlakuan P4 sebesar $5,50 \mathrm{~cm}$ terhadap panjang mutlak ikan lele. Sementara, hasil uji lanjut Duncan menunjukkan bahwa perlakuan frekuensi pergantian tanaman eceng gondok setiap 14 hari sekali (P4) memberikan nilai panjang mutlak benih ikan lele yang lebih baik dan berbeda nyata dengan semua perlakuan lainnya. Hal ini diduga karena penggunaan eceng gondok sebagai fitoremediator media budidaya dalam memperbaiki kualitas air. Menurut penelitian yang dilakukan oleh Abdul (2014), bahwa pemberian eceng gondok sebagai fitoremediator pada wadah budidaya berpengaruh secara tidak langsung terhadap pertumbuhan panjang mutlak ikan gurami. Hal tersebut ditunjukkan dengan hasil pertumbuhan panjang mutlak yang terbaik dengan perlakuan pemberian eceng gondok. Hasil tersebut memberikan kesimpulan bahwa dengan adanya eceng gondok dalam media budidaya dapat menyisihkan sisa metabolisme organisme dan pakan, sehingga menghasilkan pertumbuhan panjang mutlak yang semakin tinggi.

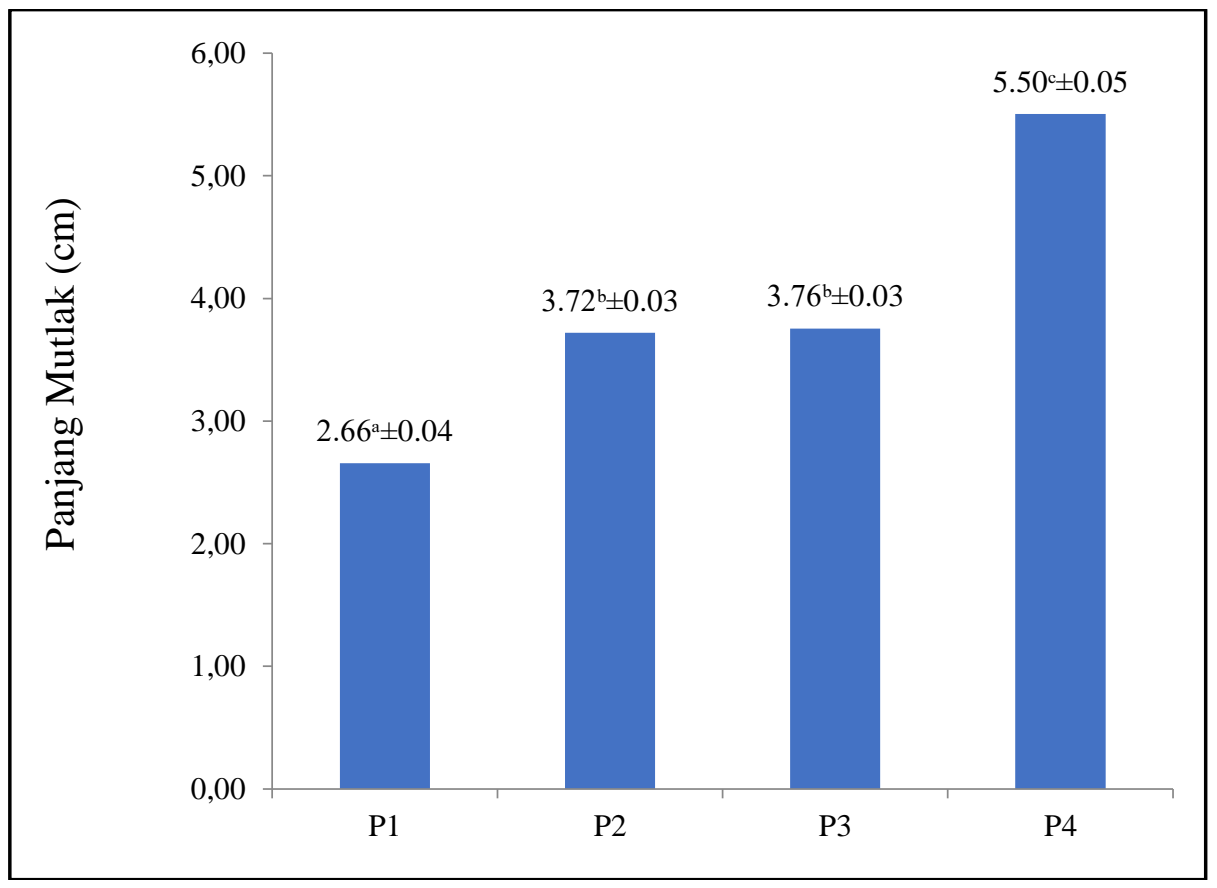

Gambar 3. Pengaruh Frekuensi Pergantian Tanaman Eceng Gondok Terhadap Panjang Mutlak Benih Ikan Lele (C. gariepinus)

\section{Berat Mutlak Benih Ikan Lele}

Berat mutlak ikan lele yang dipelihara selama 42 hari berkisar antara $6,20-9,80 \mathrm{~g}$. Secara umum Trend berat mutlak benih ikan lele meningkat sejalan dengan peningkatan frekuensi pergantian eceng gondok. Nilai rata-rata tertinggi terdapat pada perlakuan frekuensi pergantian eceng gondok setiap 14 hari sekali (P4) sebesar 9,80 g, sedangkan yang terendah pada perlakuan frekuensi tanpa eceng gondok (P1) sebesar 6,20 g (Gambar $4)$.

Hasil Analysis of variane (ANOVA) menunjukan hasil yang sangat nyata $(\mathrm{P}<$ 
0,05) dengan tingkat kepercayaan 95\% terhadap berat mutlak benih ikan lele. Hasil uji lanjut Duncan menunjukan bahwa perlakuan frekuensi pergantian tanaman eceng gondok setiap 14 hari sekali (P4) memberikan berat multak benih ikan lele yang paling baik dan berbeda nyata dengan semua perlakuan lainnya. Hal ini diduga karena penggunaan eceng gondok sebagai fitoremediator media budidaya dalam memperbaiki kualitas air berlangsung dengan baik. Hasil pengukuran Ammonia pada perlakuan P1 menunjukan kisaran nilai yang lebih tinggi dibandingkan dengan perlakuan P2, P3 dan P4. Akumulasi Ammonia merupakan faktor pendorong perubahan kualitas air sehingga dapat terjadi hambatan pertumbuhan (Komarawwidjaja, 2003). Kandungan Ammonia yang tinggi diperairan dapat menyebabkan toksik pada perairan (Unisa, 2000). Toksik dari Ammonia yang terakumulasi menyebabkan organ tubuh ikan mengalami gangguan dan menyebabkan ikan kurang nafsu makan, sehingga pertumbuhannya menjadi lambat. Menurut Nisrina (2013) bahwa kualitas air buruk menyebabkan protein yang seharusnya digunakan sebagai sumber energy untuk pertumbuhan ikan menjadi lebih banyak digunakan untuk mempertahankan diri dari lingkungan yang buruk.

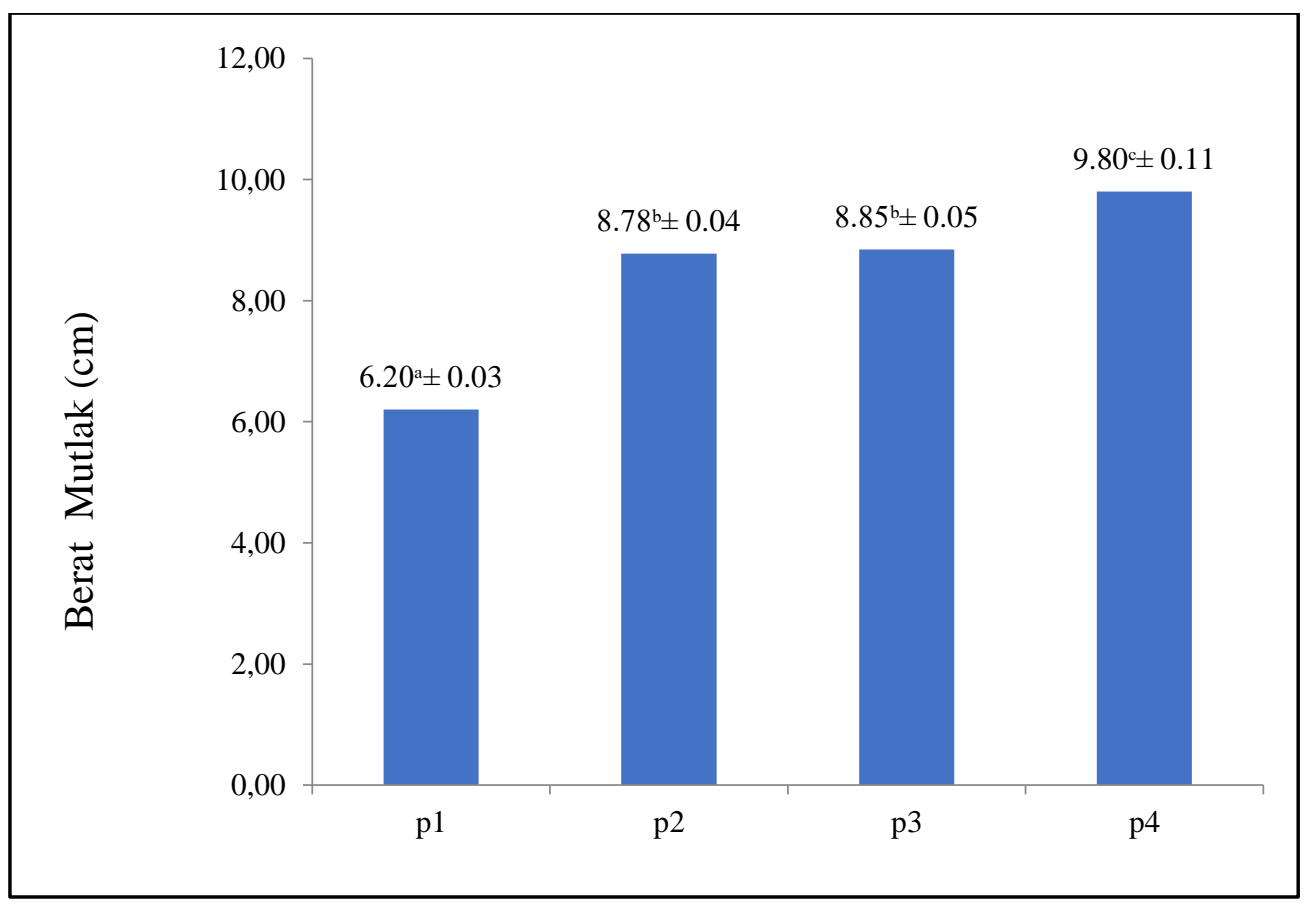

Gambar 4. Pengaruh Frekuensi Pergantian Tanaman Eceng Gondok Terhadap Berat Mutlak Benih Ikan Lele $(C$. gariepinus). (Ket : P1 = Kontrol, P2 = Tanpa pergantian Eceng Gondok, P3 = pergantian Eceng gondok hari ke-21, P4 = pergantian eceng gondok hari ke-14)

\section{KESIMPULAN}

Pemanfaatan eceng gondok (E. crassipess) pada budidaya ikan lele ( $C$. gariepinus) dengan teknik pergantian eceng gondok setiap 14 hari dapat memberikan kadar TAN yang paling rendah yaitu 0,01

$\mathrm{mgl} / \mathrm{L}$ dan memberikan tingkat kelangsungan hidup yang paling tinggi yaitu $89,88 \%$, serta pertumbuhan berat dan panjang mutlak benih ikan lele yang paling tinggi yaitu berturutturut $9,80 \mathrm{~g}$ dan $5,50 \mathrm{~g}$. 
KAUDERNI : Journal of Fisheries, Marine and Aquatic Science

https://jurnal.stplpalu.ac.id/index.php/kauderni/index

Volume 2, Nomor 2, (2020)

ISSN 2541-0571

https://doi.org/10.47384/kauderni.v2i2.45

\section{REFERENSI}

Abdul, N. 2014. Peranan Eceng Gondok Sebagai Fitoremediasi di Media Budidaya ikan Gurami Lac. Ukuran 3 cm Dalam Wadah Terkontrol. Skripsi. Institut Pertanian Bogor. Bogor.

Effendi, M. I. 2002. Biologi Perikanan. Pustaka Nusatama.

[EPA] Environmental Protection Agency. 2013. Aquatic Life Ambient Water Quality Criteria for AmmoniaFreshwater. United States Environmental Protection Agency, USA. 822-R-13-001.

Hastuti S, dan Subandiyono. 2015. Kondisi Kesehatan Ikan Lele Dumbo (Clarias gariepinus, Burch) yang Dipelihara dengan Teknologi Biofloc. Jurnal Saintek Perikanan. 10(7): 74-79.

Hermawan, A. T, Iskandar, dan Ujung. S. 2012. Pengaruh Padat Tebar Terhadap Kelangsungan Hidup Pertumbuhan Lele Dumbo (Clarias gariepinus Burch) di Kolam Kali Menir Indramayu. Jurnal perikanan dan kelautan. 3(3): 85-93.

Komarawidjaja. W. 2003. Pengaruh Aplikasi Konsorsium Mikroba Penitrifikasi Terhadap Konsentras iAmonia (NH3) Pada Air Tambak. Jurnal Teknologi Lingkungan P3TL-BPPT. 4(2): 62-67.

Nisrina. 2013. Pengaruh Pemberian Bromelin

Terhadap Tingkat Pemanfaatan Protein Pakan dan Pertumbuhan Lele Dumbo (Clarias gariepinus). Journal of Aquaculture Management and Technology. 2(2): 57-63.

Purwaningsih, I. S. 2009. Pengaruh Penambahan Nutrisi Terhadap Efektivitas Fitoremediasi Menggunakan Tanaman Eceng Gondok (EichhorniaCrassipes)
Terhadap Limbah Orto-Klorofenol. Jurnal Rekayasa Proses. 3(1): 5-9.

Pratiwi, D. 2015. Pemanfaatan fitoremediasi eceng gondok Eichornia crassipes dalam produksi ikan nila Oreochoromis niloticus ukuran $5 \mathrm{~cm}$. Skripsi. Institut Pertanian Bogor. Bogor

Putri, S. 2014. Pemanfaatan Bakteri Heterotrof Terhadap SR dan Laju Perumbuhan Ikan Lele Dumbo dengan Sistem Tanpa Pergantian Air. Skripsi. Universitas Airlangga. Surabaya.

Rahmaningsih, H. D. 2006. Kajian Penggunaan Eceng Gondok Eichornia crassipes Pada Penurunan Senyawa Nitrogen Efluen Pengolahan Limbah Cair PT. Capsugel Indonesia. Skripsi. Institut Pertanian Bogor. Bogor.

Rika. 2008. Pengaruh Salinitas Terhadap Pertumbuhan dan Kelulushidupan Ikan Hasil Strain Gift dengan strain Singapura. Skripsi. Universitas Diponegoro. Semarang

Tosepu, R. 2012. Laju Penurunan Logam Berat Plumbum $(\mathrm{Pb})$ dan Cadmium (Cd) Oleh Eichornia crassipes dan Cyperus papyrus. Jurnal manusia dan Lingkungan. 19(1): 37-45.

Unisa. 2000. Pengaruh Padat Penebaran terhadap Pertumbuhan dan Kelangsungan Hidup Benih Ikan Lele Dumbo (Clarias gariepinus) dalam Sistem Resirkulasi dengan Debit Air 33 L pm/m³. Skripsi. Institut Pertanian Bogor. Bogor.

Wulandari, N. 2015. Pemanfaatan Limnobium sp. Sebagai Fitoremediasi pada Produksi Benih Ikan Nila Ukuran 4-5 cm. Skripsi. Institut Pertanian Bogor. Bogor. 